\title{
Between Law and the Nation State: Novel Representations of the Refugee
}

\author{
SIMON BEHRMAN
}

\section{Abstract}

Given the degraded profile of the refugee in contemporary discourse, it is tempting to seek alternatives from a rich tradition of literary tropes of exile. However, this article argues that the romanticized figure of the literary exile ends up denying, albeit in positive terms, a genuine refugee voice, as much as the current impersonal hegemonic concept of the refugee as found in law. Ultimately, the spell in which refugees find themselves trapped today can be broken only by opening up a space of politics in which the refugee herself can be heard.

\section{Résumé}

Étant donné le profil dégradé des réfugiés(e)s qui existe au sein du discours contemporain, la tentation de trouver d'autres possibilités d'approche à partir d'une riche tradition de figures littéraires de l'exil s'impose. Cet article maintient, cependant, que la figure romantique littéraire de l'exil aboutit, bien qu'en termes positifs, à un reniement de la voix authentique des réfugié(e)s, au même titre que la conception hégémonique et impersonnelle des réfugié(e) $s$ que l'on trouve actuellement dans la législation. En fin de compte, le sort qui tient les réfugié(e)s prisonniers ne peut être brisé que par la création d'un espace dans la dimension politique qui puisse donner voix aux réfugié(e) s eux-mêmes.

\section{Introduction}

7 he figure of the exile in literature, or the literary figure in exile is a familiar, if not in fact a hackneyed one. ${ }^{1}$

However, over the last fifty or so years, this tradition has died out. In its place we find, instead, the exile not so much as hero as victim; shamed rather than valorized; an object of history as opposed to being an active shaper of her own life and of the broader sweep of events. The refugee is no longer a romantic figure, overcoming tragedy to triumph. In this article I identify two major reasons for the break between the exile literatures of the past and those of the present. The first is the post-colonial settlement, which has left us with a fairly rigid international state structure, demarcated with borders that are becoming ever-more policed and impassable. Previously migrants of all types had benefited from much more contingent spaces, that is to say spaces in which sovereignty was contested, often overlapping or in flux, and where there were little to no border controls. Second, the advent of the international refugee law regime has transformed the asylum-seeking process from one dominated by rival political or religious ideologies, in which refugees were often active subjects, to a highly bureaucratized process focused on categorizing and managing the movement of migrants.

In this depoliticized and delegitimized nadir of the refugee, perhaps one place to seek out her voice is in literature. There is now a rich stream of writing on the relationship between law and literature, which variously seeks out law as described in literature, law as itself a literary form, and other parallels. ${ }^{2}$ It is sometimes claimed that whereas law presents itself as Truth, literature offers itself as an artful reflection of reality. Therefore, there is a space within literature in which the monolithic narrative of law can be ruptured. 3 But equally, the relationship can flow in the opposite direction, whereby hegemonic legal concepts become reflected in literature and beyond into the wider culture. In short, as Kieran Dolin notes, works of literature "may question the boundaries established by the law, or they may simply reflect such boundaries."4 So in this article, while attempting to show 
how images of refugees are passed into literature from the law, I am also interested to see whether or not literature, in turn, creates what Edward Said has described as an "affiliative" space, within which the refugee can be reimagined. In The World, the Text and the Critic, Said describes "filiation" as the adherence to a tradition-including "a party, an institution, a culture, a set of beliefs, or even a world-vision." 5 "Affiliation," on the other hand, is also an order, but one to which one consciously adheres. Filiation is an example of a "natural" or established order-filial, the father, etc. Thus the "filiative scheme properly belongs to the realms of nature and of 'life,' whereas affiliation belongs exclusively to culture and society." The real problem arises when social orders are presented as filiative, and thus natural and fixed, law and the nation-state being prime examples, seen as inescapable facts of a well-ordered, civilized life. It is therefore the job of critical pursuits, whether academic, literary, or political, to intervene and disrupt in ways that are "affiliative." Thus, in relation to the refugee, I am seeking here to interrogate the extent to which the pseudo-filiative subjects of law and the nation-state are reinforced or challenged within the supposed affiliative space of literature. I do this through a reading of three novels-Exodus by Leon Uris (1959), Shame by Salman Rushdie (1984), and Refugee Boy by Benjamin Zephaniah (2001) - that cover the period of transition from the refugee as hero to that of victim or threat.

From Hannah Arendt through to contemporary writers such as Liisa Malkki and Philip Marfleet, the role of the nation-state in the creation of the modern refugee subject has been clearly laid out.7 The "imagined community" of the nation, founded upon notions of belonging based on a shared culture, language, and space necessarily also produce the subject of an alien other against whom the nation defines itself. ${ }^{8}$ The twentieth century is littered with bloody examples of this phenomenon-the great "unmixing of peoples" following the collapse of the Ottoman and AustroHungarian Empires, the partition of India and Pakistan, the creation of the state of Israel, the collapse of Yugoslavia. What is interesting, however, is that in each of these cases, along with many others, the refugee subject had a dual aspect. For as well as being the alien other of one state, that negative image had a positive one as the human material of a new state. As Arendt saw, those refugees who had no connection with any state whatsoever faced the ultimate degradation. In the 1930s this was the fate of the European Jews, now it is the reality of the Palestinian diaspora. One interesting aspect of Exodus is the valorization of the former through their striving towards statehood. However, today the post-colonial settlement has, for the most part, closed off the route to valorization via the creation of new states. ${ }^{9}$ The experience of most refugees today therefore is that of a "waste" product either warehoused in the archipelago of camps and detention centres or shunted around borders and seas in search of asylum. ${ }^{10}$

Another fundamental difference between refugee literature then and now is that up until very recently the legal process played, at most, a marginal role in their narratives. This can be easily explained. Until the twentieth century the legal category of the refugee did not exist. ${ }^{11}$ One of the first encounters between the refugee and law that we can find in literature is W.H. Auden's Refugee Blues. Written in 1939, this poem reflects the experiences of refugees in the age of passports, border controls, and the first abortive attempts at defining and ordering the refugee in international law. ${ }^{12}$ Describing the experience of a Jewish couple arriving somewhere from Nazi Germany, the fourth stanza reads:

The consul banged the table and said,

"If you've got no passport you're officially dead":

But we are still alive, my dear, but we are still alive. ${ }^{13}$

The equation of death with lack of citizenship-civic death-is, with the exception of that other law-bound epoch, ancient Rome, a peculiarly modern concept. Only fifty years before Refugee Blues, refugees were able to move across Europe and gain asylum with few restrictions. ${ }^{14}$ Today, of course, the experience of reaching a potential country of asylum lacking a passport, visa, or other bona fide document is a common one. So too the refusal of asylum for this lack is also all too common an event today.

Just a few years after Auden's poem we find a similar concern with legal documentation as a necessary pathway to asylum in the classic film Casablanca (1942). ${ }^{15}$ Daniel Steinbock makes an excellent case for the film as revealing the ideological framework that would, within a decade, determine the shape of international refugee law. ${ }^{16}$ Casablanca preaches the morality of assisting the refugee to find asylum. Yet, as Steinbock demonstrates, there are two important qualifications. First, it is up to a decision-maker (represented in the film by Rick Blaine) to weigh up just who deserves asylum. Second, the image of the deserving refugee is one of almost unbelievable worthiness. Victor Laszlo is a political refugee from a criminal regime, whose character demonstrates almost no flaws. Instead he is repeatedly shown to be a man of the highest moral probity, unfailingly polite, speaking impeccable English, and always well dressed. This is all a far cry from the reality of most refugees from the Nazis, who were often of far less means and forced to skate difficult lines of moral judgment in order to survive. This is not to denigrate these or indeed any other refugees. The point is that no one is able to achieve the kind of uncomplicated goodness of a Victor Laszlo. It is telling 
that such a fictional construct is necessary in order to earn our sympathy. In the age of refugee law, of judgment on who is or is not a genuine and deserving refugee, we must believe that the claimant's credentials are of the highest standard. This type of characterization can be seen as closely linked to an equally flat and romantic construction of the refugee within refugee law. The legal category of refugee rests upon certain criteria, which perhaps have more to do with what we consider to be an ideal-type rather than reflecting the myriad reasons for forced migration. The 1951 UN Refugee Convention, which is the foundation of international refugee law, insists that a genuine refugee must have left the borders of her country of origin, and that her persecution is for very particular reasons to do with religious or political belief, or due to her race, nationality, or social group. ${ }^{17}$ In other words, only those who have demonstrated will, the ability to travel, and usually some traits of courage and/or tragedy can be "genuine" refugees. So in Casablanca, and as we shall see, in Exodus, Shame, and Refugee Boy too, the affiliative space opened up leads in fact to a reaffirmation of the filiative categories of law.

What should become apparent as we journey with the refugees at the heart of these three novels is that we have moved from one idealized trope of the refugee to another, neither of which captures the complexities of the refugee experience. The voices we hear in these narratives tend to ventriloquize for forces beyond themselves-the nation, the law-whereas the earlier literature of exile tended to focus on the voice of a single individual resisting the tides of fate. At the same time, the narrative structure of the novel does at least allow us a window onto the experiences of the contemporary refugee that is all too often obscured by the statistics and headlines that dominate the discourse on migration today.

\section{Exodus: A (Nation) State of Being}

\section{The Refugee as Hero ...}

Leon Uris's novel Exodus tells the story of the creation of the state of Israel from the arrival of the first Jewish refugees from Europe in the latter half of the nineteenth century through to the establishment of the state in $1948 .^{18}$ Many of the protagonists are clearly presented as archetypes of the phenomenon of the Jewish flight from Europe, fleeing the pogroms and later the Nazis. The tale of the two brothers Jossi and Yakov who are forced to flee their home in Russia for Palestine in the 188 os stands in for the many thousands more who left the Pale of Settlement in the closing decades of the nineteenth century. ${ }^{19}$ The tale of their three-and-ahalf-year trek to Palestine is described in the most heroic terms, as they trudge through snow, "bending their young bodies against howling winds." ${ }^{\circ}$ By the time they reach the
Promised Land they have achieved almost superhuman proportions: "Jossi had grown into a lean and leathery giant six feet three inches tall with a frame of steel." ${ }^{21}$ Karen Clement's experiences mirror those of Jews forced to flee after the Nazi takeover in 1933, and their subsequent march through Europe. And finally, Dov Landau's story follows those who, after suffering the degradations of the death camps, were then spat out into the displaced persons (DP) camps at the end of the war. These successive waves of refugees are referred to in Zionist historiography as the aliyahs. The first aliyah is often called the farmers' aliyah, including those such as Jossi and Yakov who arrived in the last decades of the nineteenth century. "[The] Second Aliyah [1904-14] brought ideals and leaders and the Third Aliyah [1919-23] brought the pioneers - the German Aliyah [post-1933] resulted in a tremendous cultural and scientific spurt in the Yishuv."22 Thus each successive wave of refugees is celebrated not for who they are, but rather for what they will contribute to the founding of the nation. Heroic as they are, their identities are collapsed into the "national order of things."23

Before we see the refugees themselves, we are introduced to them through the eyes of the British military officers in charge of a DP camp in Cyprus, where they are being held virtually prisoner in terrible conditions. The anti-Semitic officer Major Caldwell refers to them as "unruly" and in need of "some good old-fashioned discipline." 24 But Brigadier Sutherland cautions that not only are the DPs not criminals but that "they've got world sympathy on their side." ${ }^{25}$ Later, when a boatload of refugees are on hunger strike demanding that the British authorities allow them into Palestine, a general orders that the whole affair must be handled with "great tact," for "no one wants to ride herd on a bunch of downtrodden refugees ... they have a great deal of sympathy on their side in high quarters ... We want nothing to happen to create an unfavourable opinion." ${ }^{26}$ Thus we have a clear picture of the refugee as one who commands sympathy and respect from wider society, if not from the authorities. This solidarity, or at the very least empathy, is, therefore, what gives the refugees real protection and a certain guarantee of sanctuary, irrespective of their legal status. A political judgment on the refugee question, rather than a purely legal one, was still in play at this time, and worked to the refugees' advantage.

A second important and rare aspect of Exodus that follows is the celebration of "illegal immigration" as a heroic act. Indeed the mass of refugees is conceived of as part of the Zionist army of liberation. "Illegal immigration ... that is the way we will fight them," says Avidan, the commander of the Hagganah. ${ }^{27}$ This is an accurate reflection of the Zionist project, which championed such immigration as a weapon against the Arab majority then living in Palestine, as well 
as the British Mandate authorities. And it is this aspect that is crucial to the sympathetic portrayal of refugees in the novel, for the Jewish refugees are not fleeing their homelands but are returning to it. That is, according to Zionist ideology, they are returning to a land that is rightfully theirs, in order to build their nation. When Zionist agents break into a DP camp in Cyprus, they "set up schools, hospitals and synagogues, [build] sanitation facilities, and [organize] light industry." 28 It is the impact of a political ideal framed in terms of an identity rooted in nation that raises the refugees to the level of a "civilized" community. Further, the camps are turned from ones of internment into centres for the eventual struggle in Palestine, with the Zionist agents training the refugees in military tactics, "Arab psychology," and Palestinian geography. ${ }^{29}$ At the end of the novel the emigration of the Yemeni Jews to the newly created Israeli state is framed in similar terms. Initially they are "tragic figures ... dressed in rags, filthy and half dead"; they are "semi-primitive people."30 But on arrival in Israel they are cleaned up and introduced to civilization in the form of "motor vehicles, medicine, western dress." In short, they really become human only with their subsuming into the modern nation-state. The final transformation of the refugee Jossi into the heroic figure of the novel is his adoption of a Hebrew name-Barak Ben Canaan-and his insistence on speaking Hebrew instead of Yiddish. When his wife resists this, he responds, "Yiddish is the language of exiles. Yiddish is the language of the ghetto. Hebrew is the language of the Jews." ${ }^{1}$ Thus, in multiple ways the illegal immigrants are ultimately valorized only through their role as creators of the nation-state.

\section{... to the Refugee as Threat}

The contrast with the portrayal of the Arab refugees during the war of 1948 is stark. They are described in impersonal and faintly bestial terms. There are no individual characters drawn for us to give them life and a multi-dimensional image. Instead they are described as a mass "stampeding" in their flight from their homes. In Acre the Arab refugees resist in only a "half-hearted" and "feeble" manner. This weakness then spreads like an "infection" to other Arab centres..$^{32}$ Repeatedly throughout the novel the Arabs are set up as a foil for the nobility of the Jewish refugees. This is done either by presenting the Jewish refugees as tragic victims, or as heroic nation-builders and cultivators of the land. Brigadier Sutherland describes seeing the Arab slave markets and hand amputations, and then contrasts them with witnessing the plight of the Jews in Belsen.33 When Jossi and Yakov arrive in Palestine, they find that the land has fallen victim to "a thousand years of Arab and Turkish neglect." 34 It will be the task of these refugees to "make the desert bloom." Here the "host" community is othered, while it is the refugees who are valorized as bringing economic development and civilization. Amongst other things, what the Palestinians lack and what the Zionist project brings is the nation-state.

The climax of the novel is the achievement of statehood by the Zionists. And with this development comes a shift in how the figure of the refugee is presented. After spending some 600 pages lionizing refugees as heroes and harbingers of progress, a problem arises as to how to deal with the obvious issue of the hundreds of thousands of Arabs forced from their homes during the violent establishment of the state of Israel. Uris adopts a number of literary and political frameworks to mark out the distinction between the sets of refugees. First, the Arab exodus is dealt with not in narrative, not by describing the experiences of the refugees themselves. Instead, it is presented in the form of an Israeli government report prepared by Ben Canaan. This has the effect of creating distance between the reader and the refugees. Second, all the metaphors of backwardness are thrown at the Arabs-they are dupes played on by their leaders for their "illiteracy, superstition, and fanatical devotion." 35 Third, their flight is branded as being a result of "blind fear and ignorance" rather than of any genuine fear of persecution. Ergo, in the language of the law, as set out in the 1951 convention, their fear of persecution is not wellfounded. Fourth, their flight is described as being merely a political act aimed at embarrassing the Zionists. Here we have a sharp reversal following the repeated emphasis on Jewish refugees to Palestine being a politically heroic act. The difference is that the Jewish refugees are described as active subjects, whereas the Arabs are presented as objects in the hands of their malevolent leaders-"caged like animals in suffering as a deliberate political weapon." Finally, the return of the Arab refugees is ruled out on the grounds that they would be a "hostile minority, pledged to destroy the State." 36

Throughout Ben Canaan's report there are remarkably few verbs deployed to describe the Arab refugees themselves. Instead, will resides almost exclusively with the opportunist Arab leaders, with the refugees as their objects. By contrast the contemporaneous Jewish refugees from across the Middle East are endowed with their own volition. The refrain of "they came from ..." is alternated with phrases such as "walked through burning deserts," "arose from the melahs," "fought their way to ...," etc. ${ }^{37}$ The tropes of backwardness and lack of justification for flight are familiar to those used to the contemporary discourse on refugees. But for me the most striking element in this passage of the novel, which is itself an accurate reflection of Zionist historiography on the subject, is the stripping away of the political subjectivity of 
the Arab refugees, as distinct from their role as objects of political strategy. Moreover, there is the arrival of the state as a supreme subject whose rights outweigh those of the refugees. The sanctity of the nation-state, even a nascent one, is asserted against the threat of the refugee mass. In short, Uris has used literary forms to frame the transformation of the affiliative project of Zionism into the filiative state. So here literature has been used to both open up and then close the affiliative space. The voices of refugees engaged in making and shaping the world around them have been silenced in the face of the unimpeachable priority of state preservation. In Exodus, as in the actual historical events it describes, this phenomenon is presented in concentrated form. Key to this process is the encrustation of political and ethical notions of justice-e.g., the need for Jews to find safety from persecution in Europe, the right of Arab Palestinians to return to their homes, etc.- - with a colder, more impersonal juristic view on their plight. The fact that the problem of the Arab refugees is dealt with by Uris using the literary form of a government report, and an emphasis on the threat to state security by their return, is emblematic of this legalistic turn. The reasons can be glimpsed at the very beginning of Ben Canaan's report, when he describes the Arab refugee problem as "the most potent political weapon in the Arab arsenal"; ${ }^{38}$ echoes here of the British Mandate authorities' concern that the Jewish refugee arrivals in Palestine had "world opinion on their side." So long as the cause of refugee protection is seen as just in itself, states find themselves forced to admit them. A recent example of such a phenomenon was the widespread sympathy for refugees crossing the Mediterranean, sparked by the shocking images of their plight hitting news bulletins and front pages, which pushed a number of EU states to temporarily suspend the normal legal restrictions imposed on their movements. The task for the state in such situations, therefore, is to delegitimize the cause of the refugees. One of the most powerful methods of doing this is to reframe claims for asylum in legal rather than purely political terms. Failure to meet the legal standard leads ipso facto to the illegitimacy of the claim and the perception that the problem lies with those seeking to abuse the system of refugee law, rather than those enforcing it. The judgment of the law is final, whereas in the political sphere, claims can be infinitely contestable. The extent of the factual inaccuracies and political prejudices that can be found throughout Exodus call into question its value as a historical novel. ${ }^{39}$ However, what it does offer us is a window on a historical turning point in which the refugee hero of putative nation-states became the sinister and pathetic mass who threaten the nation-state order. The temporal frame of this change in Exodus covers almost seventy years, and indeed during this period the shift was incremental. Moreover, the novel closes in the late 1940s, on the cusp of the great process of decolonization that swept the globe, and just before the laying down of the first comprehensive international legal regime regulating the movements of refugees. In the next two novels, we witness the effects and after-effects of these later events.

\section{Shame: The Refugee Stripped and Revealed}

The titular theme of Salman Rushdie's novel Shame begins with the shame of refugeehood. 40 The violence that accompanies the partition of India and Pakistan launches the infamous mass exodus in both directions across the newly created frontier. For Bilquis Kemal (soon to be the wife of Raza Hyder, loosely based on the real-life General Zia UlHaq), Partition sees her fleeing from her home when a sectarian bomb blows apart her father's cinema, and their house that lies behind it. The shawl that covers Bilquis's naked body is burnt to mere threads by the force of the blast, and her eyebrows are permanently singed off her face. It is only as she has fled along with many others that she becomes aware of her nudity, and cries with shame. No one listens or responds, as they are all in panicked flight too. The stripping of Bilquis's modesty is offered by Rushdie as a metaphor for the exposure of refugees to the vicissitudes of their fate: "All migrants leave their pasts behind, although some try to pack it into bundles and boxes-but on the journey something seeps out of the treasured mementoes and old photographs, until even their owners fail to recognise them, because it is the fate of migrants to be stripped of history, to stand naked amidst the scorn of strangers upon whom they see the rich clothing, the brocades of continuity and the eyebrows of belonging." 41

The shame of Bilquis's physical nakedness thus stands for the shame of the refugee stripped of all attributes of modern civilization-rootedness, community, and belonging. Here we may pause to consider Giorgio Agamben's use of the term la nuda vita (bare life) to describe the modern refugee along with all those others who have been stripped of the accoutrements of a civilized life, indeed of any life beyond mere existence. ${ }^{42}$ Bareness and nudity in Italiannuda-(and the French nue) are one and the same term. The nudity of Bilquis is certainly a source of shame, and that is how Rushdie adopts it as his metaphor. But bareness can also be positive- "the naked truth," or as it is expressed in Italian, la verità nuda e cruda. The Oxford English Dictionary gives various definitions for bare such as "Stripped of surroundings, contents, property. Defenceless, unprotected, deserted"; "Laid waste, desolate"; "Without possessions, destitute, indigent, needy"; "Poor in quality, paltry, worthless." But it can also mean "To make or lay bare, uncover, open to view”; “To disclose, reveal, make manifest.” In Agamben's 
work, we can certainly see both senses of the term at work: life stripped of any meaning beyond existence, but also a life that although seemingly at the margins reveals, uncovers something fundamental to the hegemonic form of life created by juridically constituted sovereign power. Agamben's thesis echoes Rushdie's evocation of the rootlessness of urban life when he describes the city as "a camp for refugees." 43 Thus Bilquis's nudity is not just her shame, but also a striking exposure or revelation of the refugee experience in the twentieth century. Her shame along with that of the millions of her fellow refugees, and the subsequent attempts to overcome it through the construction of a nation-state founded upon war and military glorification, will lead to a denouement where refugeehood is revisited, only this time as abject tragedy. Once again, just as with Exodus, attachment to a romanticized figure of the refugee as nationbuilder will end with the transformation of the refugee subject into its flip side: pathetic victim.

For Bilquis, flight and her shame lead her to apparent happiness when she meets her future husband Raza in the makeshift refugee encampment. Here they marry "beneath the bitter eyes of the dispossessed multitudes." Already Bilquis is trying to absolve her shame by rising above the embarrassing mass of fellow refugees around her. Their wedding is carried out, "isolated behind [a] screen from the dull, debilitated anger of the mob ... 'Tch tch,' she reproached the glowering refugees, 'but this envy is too terrible thing." "44 The newlyweds move on to Pakistan-the "bright new world" of the new nation-state, of an end to statelessness and bare life. Indeed, Raza is able to offset some of the shame of being a refugee when his first successful military exploits in the war following Partition demonstrate "the advantages of the energy-giving influx of immigrants." 45 Here affiliation is key, the refugee an active subject of history. The shame of rootlessness is expiated by the founding of a new polis within which the refugees can rebuild their identities. They are able to do this through being the architects of their own subjectivity. But, and this is the crucial point, their revival as valorized subjects is inextricably linked to the nationstate, as was the case for the Jewish refugees in Exodus.

In response to the insult of "Mohajir! Immigrant!" thrown at Bilquis, Rushdie as narrator steps forward in an extended passage to ruminate on the migrant experience:

I, too, know something of this immigrant business. I am an emigrant from one country (India) and a newcomer in two (England, where I live, and Pakistan, to which my family moved against my will) ... The anti-myths of gravity and of belonging bear the same name: flight ... To fly and to flee: both are ways of seeking freedom ... When individuals come unstuck from their native land, they are called migrants. When nations do the same thing (Bangladesh), the act is called secession. What is the best thing about migrant peoples and seceded nations? I think it is their hopefulness. Look into the eyes of such folk in old photographs. Hope blazes undimmed through the fading sepia tints. And what's the worst thing? It is the emptiness of one's luggage. I'm speaking of invisible suitcases, not the physical, perhaps cardboard, variety containing a few meaning-drained mementoes: we have come unstuck from the land. We have floated upwards from history, from memory, from Time. ${ }^{46}$

Here Rushdie expresses the dual nature of exilic movement as both positive and negative, dreaming of flight, freedom, but also the emptiness, the draining away of identity. Partially this duality has to do with the blurring of the distinction between forced and voluntary migration. For those forced to flee, their hope is often limited to an end to the persecution or other dangers that they have led to their flight. But as Liisa Malkki, adopting the same metaphor as Rushdie, has written, "People who are refugees can also find themselves quite quickly rising to a floating world either beyond or above politics, and beyond or above history-a world in which they are simply "victims."'47 This is recognized at the climax of Shame, when Bilquis and Raza are once more forced to flee, only this time not to forge a new nation-state, but rather as is the case with most refugees in modern times, simply to seek safety. Here the description of their flight is raw, of little to eat, drinking water from dirty lakes, the constant fear of capture before crossing the frontier, and finally their vulnerability in their apparent sanctuary leading to a shameful death bathed in their own filth: "There is no country poorer than Escape." 48 Thus the duality of exile that Rushdie describes reflects both an older romantic exile familiar from literature-the Dantes and the Robinson Crusoes-for whom forced migration represents a journey of discovery, a figurative view from above, and also the banal realities faced by most forced migrants.

One arc of the novel is that from the heroic refugee who rises above the shame of the bareness of refugeehood through the construction of a new national identity to the refugee of today, deprived of any opportunity to reassert her active subjectivity, who must instead rely on the passive and precarious reliance on survival and help from others. What links the two ends of this trajectory is a two-dimensional subjectivity imposed upon complex characters. The romanticized refugee subject whose flight becomes the basis of the founding of the nation-state is but a cypher for that political project. Once the project is completed, the rootlessness of the refugee becomes instead an embarrassment, an affront to the pride of the nation. And so, again, once the affiliative space has closed, replaced by the bordered space of the state, the refugee finds herself excluded and despised. A similar 
trope is at work at the end of Exodus, with the depictions of the post-independence Arab Jews. Whereas once the refugee reflected the aspirations for a nation-state, in the post-colonial context she has, as Arendt and Agamben have identified, become a symbol of those who lack that ultimate modern signifier of civilization: citizenship. However, it should be noted that with Rushdie, the opening and closing of the affiliative space is presented as what it is: a reversal in the fortunes of the refugee. Rushdie thus uses literature as a means to trouble and destabilize established notions of the refugee subject, whereas in Exodus the literary forms deployed are used to reinforce them.

\section{Refugee Boy: Dehumanized by Law, Re-Humanized by Politics}

Refugee Boy by Benjamin Zephaniah, published in 2001, represents a decisive change in refugee literature. 49 The flux of decolonization, which allowed for at least some space for the heroic refugee in Exodus and Shame, has been replaced by the hegemony of the "new world order." In Refugee Boy, in addition to the post-colonial context, a second and highly virulent phenomenon is also visible in the refugee experience: the legal process of seeking asylum. Half a century after the 1951 Refugee Convention, and in the immediate wake of a succession of pieces of asylum legislation in the United Kingdom, the refugee as shaped by and shaper of great historical events has given way to the mundanities of life in poverty, reliance on the host state for subsistence, and the legal process of refugee status determination. This effect is partly a result of Zephaniah's hyperrealist style. But by the same token this realism accurately reflects a historical phase in which the refugee subject, as expressed through political discourse and legal structures, has indeed been stripped of her heroism and place in the making of history. Therefore, in this novel the struggle of the refugee has been shifted from the realm of world historical events to the much narrower space of law. The examples that we have looked at so far-the creation of the states of Israel, India, and Pakistan-have all passed into our collective consciousness as epoch-making events. Moreover, the refugees in all these situations were bearers of hope for progressive change. In Refugee Boy, however, the refugee in question, a teenaged boy fleeing the war between Ethiopia and Eritrea, is a product of a conflict existing at the periphery of contemporary globalized consciousness. Indeed, insofar as most people in the West register this region in their consciousness, it is in the images of abject suffering and victimhood that were popularized by the Band-Aid phenomenon of the mid-1980s: "Do they know it's Christmas time?"-a question that could be asked only about people seen as far beyond the borders of civilization. Of course, this problem of marginality is due partly to the endemic racism that persists, even in our post-colonial epoch. Yet we do not have the same sense of distance from the refugee-producing events in Uris's Exodus and Rushdie's Shame, which also deal with situations arising in the Global South. The question of Palestine was dominated by the machinations of European powers, and the partition of India and Pakistan was related directly to the fall of the British Raj, and thus these events were intimately and obviously connected to the politics at the centre of global power. For sub-Saharan Africa today, systematically raped by Western corporations for its natural resources, but politically long-since independent from the polities of the West, the wars of the continent are in the collective consciousness there merely quarrels "in a faraway country between people of whom we know nothing."50 Yet, as we shall see, while Refugee Boy represents in key respects a further qualitative move away from the refugee literature of the past, it still ends up cleaving closely to a romanticized refugee subject capable of being valorized within the dominant discourse.

A central feature of the refugee experience today around which the narrative of Refugee Boy pivots, one that was either unknown or peripheral to refugees previously, is the grinding process of refugee status determination. The post-colonial absence of a grand political project of nationbuilding leaves refugees from the Global South almost wholly dependent on legal definitions as justification for asylum. The juridical process has the effect of creating subjects stripped bare to the essentials of the legal definition, and to the resulting passivity and dependence upon the host country. Legal categorizations, such as that of refugee, can be the ultimate in filiative spaces. In other words, questions of belonging and acceptance that were once the subject of contestation become objectified and fixed. Zephaniah's novel powerfully evokes the feelings of alienation, confusion, and lack of control experienced by the refugee as he is forced through the legal system. This begins when Alem, the eponymous refugee boy, makes his initial claim for asylum. After he is "photographed, fingerprinted, interviewed and given a number," Alem's hearing takes place in a "menacing building" that is "grey and lacking in colour." 51 Again, this is both an accurate description of a court building and figuratively a description of the cold impersonality of the law. This is then momentarily disrupted by an expression of humanity in the hearing by Alem himself. After the judge announces an adjournment and makes the perfunctory inquiry as to whether the applicant has anything to say, Alem shocks the judge and his own counsel when he wishes everyone in the court "Happy Christmas," provoking warm laughter in the court and the judge's cold mask to slip. ${ }^{52}$ When, some weeks later, the appeal judgment is finally delivered, however, the 
judge deploys the well-worn legal cliché, "I cannot make a judgement based on emotions, I have to look at the facts," before dismissing the asylum claim. 53 This is after callously describing Alem's mother as having been "hacked" to death, causing Alem to faint in the dock. What Zephaniah sets up in the meeting between the refugee and the law is that of the human before the coldly calculating, a theme that is repeated throughout the novel.

\section{The Return of the Political}

It is at this point, the failure of the appeal, that the story shifts gear. From the cold grey scene of the court, the next chapter is entitled "This Is Politics." Alem's school friends argue with him that a campaign is needed so that he can stay. In the words of one of them, “There ain't no justice, just us." 54 These words are emblematic of a true political subject, one who not only speaks but who does so not on the terms of existing power relations but on those of a collectively self-constituted identity- “just us." Instead of allowing the law to determine the borders of belonging, the community-Alem's schoolmates, friends, foster family, along with the wider community in which he lives-expand it to include someone who in the truest sense of the term is "one of their own." Alain Badiou has coined a slogan to express this political sense of community that cuts across national or legal distinctions: "Everyone who is here is from here." 55 The lines between "them" and "us" have been reconstituted. Instead of a host community/alien binary, we have instead the powerful against all those who are or were once branded as other. Alem's friends present us with a range of these identities. Robert Fern reveals himself at one point to be really Roberto Fernandez, the son of refugees from Pinochet's Chile. Asher, born in Britain to parents from Jamaica, self-identifies as a Rastafarian and thus describes himself as an Ethiopian "who just happens to be born in England." Robert playfully picks up on this when he tells Alem, "All human life started in Africa, so I'm an African too ... an African that just happens to be born in Manor Park." 56 Finally, Ray "Buck" Buckley comes from a family that "had lived in the area as far back as they could trace, but all he wanted to do was leave the area." 57 Buck is, of course, a typical teenager yearning to leave the confines of home and school. But here his typical adolescent angst makes him identify with others who are in other ways outsiders. The community around Alem is suffused with a cosmopolitan working-class culture based on solidarity_ "Pithead," the band name of Buck and his mates is a nod to the historically heroic role of the coal miners in the British class struggleand a shared self-constructed identity of belonging together yet feeling alienated from much of "society" as it is reflected in dominant discourses. Alem's friends are thus a perfect example of Said's "affiliation," a conscious process of representation. ${ }^{8}$ Rushdie, in non-fiction mode, has written that all refugee/immigrant communities in England-from the Huguenots, through to the Jews, and more recently, those from South Asia and elsewhere-do in fact have a shared identity as "immigrant Britain," a category that by its nature is constantly in flux. 59

Following the failure of Alem's appeal, this community springs into action in defence of Alem and his father's right to be granted asylum. Initially this creates a schism between father and son. Alem's father rejects the idea of a political campaign in favour of allowing the law to take its course, the argument being that they have no right, as aliens, to engage in politics in the United Kingdom: "We certainly should not be getting involved in the politics of this country." 60 This is from a man so deeply involved in the politics of his homeland that he has been forced into exile. The refugee, in other words, once outside of his country of origin, has a right to the law but not to politics. The distinction between "genuine" and "bogus" refugees today is laid precisely on this line between law and politics, for those marked with the imprimatur of the legally constituted refugee subject are allowed (up to a point), whereas those whose claim falls outside, based on a political claim or economic need, are forbidden. Zephaniah's novel breaks through this oppressive binary by contrasting the long, grey, and inhuman legal process with the life and colour of the campaign for Alem's right to stay. Alem, in response to his father's insistence on respecting the line between law and politics argues, "Everything is politics ... We are here because of politics, the judge is there because of politics, and we are being sent home because of politics." Alem's decisive argument with his father is to repeat the quote from his friends: "There ain't no justice, just us."61

The campaign itself displays all the usual contradictory consciousness of those new to political resistance. Statements such as "As British subjects we believe that it is our duty to offer them protection" 62 mingle with slogans of the type, "There are no illegal immigrants, only illegal governments." 63 The rights of sovereign-constituted subjects confront the placing of legal judgment beyond the realm of the state. A further although undeveloped part of the narrative is the drawing in of other refugees into the campaign. This is shown through the Palestinian Abbas, who turns up at one demonstration with a placard bearing the legend, "Refugees are human, let us live."64 In this simple but direct demand rests an essential truth of the refugee experience today. Trapped in the one-dimensional identity of the legal subject, forced into a "bare life" of existence, there is the cry for recognition of themselves as multi-faceted political beings in the Aristotelian sense, as members of the polis, the community. A nice example of how the collective and 
individual subject can interact to (re)construct active subjectivities occurs at a protest for Alem and his father. Called to speak to the crowd, Alem at first resists, nervous and unsure of himself. Only after the calls of the collective for him grow louder does he tentatively take the megaphone and address the protest. In doing so, this refugee literally and figuratively finds his voice.

\section{The Romantic Subject}

One seriously problematic element of Zephaniah's novel is the portrayal of the central character of Alem, the refugee boy of the book's title. He is almost too good to be true. Never once does he behave badly, become unjustly angry or rude. He is the most studious student one could imagine, reading up on the classics of English literature any moment he gets, resisting the temptations of his friends to smoke and act up. In spite of the trauma of having to flee his home, his mother's murder, his father locked up in a detention centre for asylum-seekers, removed from his loving foster family and forced to live in a squalid hostel, humiliated by kids at his school for the gaps in his English, and all the other ritual shaming that asylum-seekers in the United Kingdom face today, Alem remains always calm and welladjusted. He charms the judge and impresses his teachers. His foster mother describes him as a role model whom everyone should look up to. This portrait, like that of Victor Laszlo in Casablanca, is idealized to such an extent that it dulls the contours of the character. Ultimately, Alem comes across as tragic and suffering yet saintly, Christ-like, the ultimate romanticized figure. Thus while the portrait is positive, it remains, like that drawn by law, an image of the refugee that is not truly human. As such he is one of the least convincing characters of the novel. One can understand that Zephaniah wishes to counter the flood of negative images that have swamped our collective consciousness. But as a result we have a character who claims our sympathy on an unreal basis. Alem is the archetypal deserving refugee-hard working, intelligent, respectful, and uncomplicated. Any refugee lacking any or all of these qualities would thus be ipso facto undeserving. Asylum is therefore still predicated on the worthiness of the individual, not on the duty to protect, or the right to sanctuary. We are invited, once again, to sit in judgment on the refugee, even if that judgment is meant to be positive. Just as in the period of decolonization in relation to the nationbuilding migrants, we appear to need our refugees to be heroes in order for them to be valorized or welcomed. We could, perhaps, see the setting up of an idealized refugee such as Alem as an attempt to create an affiliative space that could advance the place of the refugee in the general discourse. But the unreal nature of this central character unfortunately creates a narrative weakness that undermines this objective.

The problem in bringing the ideal to bear in critiquing reality was well described by Georg Lukács. The strength of the novel form, he argued, consists in the "problematic individual's journeying towards himself, the road from dull captivity within a merely present reality-a reality that is heterogeneous in itself and meaningless to the individual-towards clear recognition."65 This trope is similar to affiliation, as the protagonist struggles with her place in the world, seeking to remake her identity through conscious choices. Zephaniah presents Alem's “journeying” in such a way as to challenge the reality of refugeehood. But the failure to adequately problematize him as an individualwhere "his aims are given to him with immediate obviousness"-makes the transcendence of reality a function of idealism rather than a realist form of immanent critique. ${ }^{66}$ It is important here not to confuse these terms. I use idealism and realism here not as literary forms, but in terms of a philosophical approach to how the dominant discourse can be challenged. Refugee Boy is written in a relentlessly realist register, in the literary sense. But ultimately it falls, through the central character of Alem, into positing an idealized picture of resistance. By contrast, in Rushdie's Satanic Verses, for example, the revolt of the despised immigrant through his transformation into an aggressive beast both brings into sharp relief the bestial imagery that is projected onto the immigrant, while at the same time showing how the most base and animalistic anger is a necessary, if paradoxical, route back to reclaiming his humanity. ${ }^{67}$ Arendt too, in her essay "We Refugees," reflects on the experiences of her fellow exiles from Nazi Europe and draws out all the complex, difficult, and conflicting pressures in maintaining one's identity in a state of forced migration. ${ }^{68}$ The character of Alem fails to present a realistic refugee voice, but he is truly emblematic of the contemporary refugee subject trapped between the tropes of the dehumanized legal definition and the romanticized literary construct. Lukács has further argued that for literature to be successful it "must demonstrate both the concrete and abstract potentialities of human beings in extreme situations." 69 Potentiality is thus not about imagining some idealistic perfection, but neither is it about simply describing subjects just as they are. In a curious way Refugee Boy falls into both these traps-Alem's travails are depressingly familiar, while he appears as a character occupying Malkki's "floating world" of the refugee as victim, painted in the most sympathetic of colours.

\section{Conclusion}

Reflecting upon the literatures of exile, Said has written, "Refugees ... are a creation of the twentieth-century state. 
The word 'refugee' has become a political one, suggesting large herds of innocent and bewildered people requiring urgent international assistance, whereas 'exile' carries with it, I think, a touch of solitude and spirituality."7o Malkki comments on this passage that the literature of exile to which Said refers, one that "connotes a readily aestheticizable realm," is absent from the field of refugee studies, replaced instead by a focus on "refugees" as subjects of a "bureaucratic and international humanitarian realm."71 However, as Steinbock shows in his study of Casablanca, the romantic construct of an idealized forced migrant has largely informed the international legal definition of the refugee. The exclusion of most forced migrants from the protection of the international legal/bureaucratic order is therefore a result of the fact that the real experiences of most refugees simply do not conform to such an ideal-type. The failure of Alem as a believable protagonist is rooted in this phenomenon. Thus it is a category mistake to counterpose the aesthetic to the legal constructions of the refugee. As Kieran Dolin writes, "The notion that literature is a zone of free expression ... is an idealist one ... Consequently, it is important not to regard literature and law as 'polar opposites,' one a space of freedom, and the other an institution of social control."72 Some way must be found out of a circular discourse based around the legal definition of the refugee and the identity of the nation-state, which continually returns the figure of the refugee to the filiative realm of the objectively good or worthy subject. But as we have seen in the novels discussed in this article, we should not idealize the capacity of literary texts to guide us in this project.

The question of the refugee is political today only in a very restricted sense, framed in terms of a vague humanitarian concern or in the nation-state as a project. The problem evidenced in Exodus and Shame is that once that project of becoming a nation-state is completed, the refugees that remain become ipso facto a non-political question. And in the post-colonial age this is the fate of the overwhelming majority of forced migrants. Instead, if we understand politics as a field of rival positions irreducible to consensus or a final event, then reinvigorating the refugee question involves remaking the refugee subject in such a way that it cuts across the romantic/legal construct.73 Politics in the sense described by Jacques Rancière and Alain Badiou, spaces of contestation that cannot be collapsed into a singular consensus or ethics, has been edged out by a humanitarianism that uses a romanticized figure of suffering as its reference point. Law, on the other hand, by creating categories of rights, and therefore of rights-bearing subjects, reduces the complexities of human beings to "the significance of a mathematical point, a centre in which a certain number of rights is concentrated."74 In both cases the refugee appears as an idealized trope, which often bears little relation to the difficulties and complexities of the refugee experience. Seeking out the refugee voice is thus about reimagining and rehabilitating the refugee as an active subject, not simply as a victim of circumstances or as an ideal-type. Nevzat Soguk has written of "migratory horizons" in which "migrants make their histories as the histories of others even if 'they do not make them just as they please and under circumstances chosen by themselves." 75 The point is that finding the "true" voice of the refugee is not an end in itself, but rather a process of making and remaking that begins with recognition of the refugee as an active subject at its centre. The problem is that the scope for doing that has become very restricted, as forced migrants are forced to continually confront false images of the refugee constructed by law and the nation-state. ${ }^{6}$ Thus the seeking out of refugee voices is an endeavour that necessarily involves refugees being heard, and therefore having a chance to speak, outside of the frameworks of the nation-state and law. It might be objected that the spaces for doing that are almost impossible to find, or practically non-existent at present. However, by reading the literatures of the distant and more recent past, we can at least see that the refugee has existed in a multiplicity of guises, refreshingly distinct from the pathetic and threatening figure that hegemonizes our discourse today. Yet we must be very wary of relying on the romanticized tropes found in that realm, for all too often they have reflected or fed into, rather than challenged, the existing delineation of the refugee subject.

Simon Behrman is lecturer in law at the University of East Anglia, UK. The author may be contacted at s.behrman@uea. ac.uk

\section{Notes}

1 Ovid, The Poems of Exile: "Tristia," "Epistulae ex Ponto" and "Ibis" (Harmondsworth: Penguin, 1994); Dante Alighieri, The Divine Comedy, 3 vols. (London: Penguin, 2003-7); Daniel Defoe, Robinson Crusoe (London: Penguin, 2007); the poetry of Nazim Hikmet, especially C'est un dur métier que l'exil (Paris: Le Temps des Cerises, 2002); Miguel de Unamuno, "How to Make a Novel," in Novel/nivola (London: Routledge \& Kegan Paul, 1976); in non-fiction, Theodor W. Adorno, Minima Moralia: Reflections from Damaged Life (London: Verso, 1996). Literature in Exile, ed. John Glad (Durham, NC: Duke University Press, 1990) is an edited transcript of a 1987 conference of exiled writers. One theme that is raised by just a few participants, but that is a central concern of this article, is the gap between the experience of the writer in exile and the mass of "ordinary" refugees, with the position of 
the Gastarbeiters in Germany frequently alluded to in this context.

2 See, for example, Sanford Levinson, "Law as Literature," Texas Law Review 60 (1981): 373-403; Stanley Fish, Doing What Comes Naturally: Change, Rhetoric, and the Practice of Theory in Literary and Legal Studies (Durham, NC: Duke University Press, 1989); Peter Goodrich, Law and the Courts of Love: Literature and Other Minor Jurisprudences (London: Routledge, 1996); Richard A. Posner, Law and Literature, 3rd ed. (Cambridge, mA: Harvard University, 2009); Ravit Reichman, The Affective Life of the Law: Legal Modernism and the Legal Imagination (Stanford: Stanford University Press, 2009).

3 Maria Aristodemou, Law and Literature: Journeys from Her to Eternity (Oxford: Oxford University Press, 200o); Robin West, Narrative, Authority and Law (Ann Arbor: University of Michigan Press, 1993).

4 Kieran Dolin, A Critical Introduction to Law and Literature (Cambridge: Cambridge University Press, 2007), 8.

5 Edward Said, The World, the Text and the Critic (London: Faber, 1984), 19.

6 Ibid., 21.

7 Hannah Arendt, The Origins of Totalitarianism (New York: Schocken, 2004); Liisa H. Malkki, "Refugees and Exile: From 'Refugee Studies' to the National Order of Things," Annual Review of Anthropology 24 (1995): 495523; Philip Marfleet, Refugees in a Global Era (Basingstoke, UK: Palgrave Macmillan, 2006).

8 Benedict Anderson, Imagined Communities (London: Verso, 2006).

9 In Reference Re: Secession of Quebec [1998] 2 SCR 217, a widely cited opinion of the Canadian Supreme Court, it was held that the right of self-determination in international law does not imply an automatic right to secede from another state. The right of territorial integrity of states had to be respected, and so, the court argued, only where basic freedoms were repressed would the right of self-determination entail also the right to form a separate state.

10 Zygmunt Bauman, "Who Is Seeking Asylum-and from What?," Mediactive 4 (2005): 90-107.

11 At the level of international law, the first attempts at regulating refugee status began in the 1920 under the League of Nations and were headed up by the Norwegian diplomat Fridtjof Nansen. They was followed by attempts in the 1930 s to draw up legally binding conventions for refugees. The short-lived International Refugee Organisation (IRO) was created in 1946, ending finally with the creation of the United Nations High Commissioner for Refugees (UNHCR), which was established, in tandem with the UN Refugee Convention in 1951. The latter has established a settled system of international refugee law. Domestic laws on refugees have generally been also of twentieth-century vintage and for the last half-century have tended to follow the framework of the un Refugee Convention.
12 For example, in the 1933 Refugee Convention and the 1938 Evian Convention. For detailed discussion of this process, see Claudena Skran, Refugees in Inter-War Europe: The Emergence of a Regime (Oxford: Clarendon, 1995).

13 W.H. Auden, Collected Shorter Poems 1927-1957 (London: Faber \& Faber, 1969).

14 Bernard Porter, The Refugee Question in Mid-Victorian Politics (Cambridge: Cambridge University, 1979).

15 Casablanca, Dir. Michael Curtiz, 1942.

16 Daniel J. Steinbock, "Refuge and Resistance: Casablanca's Lessons for Refugee Law," Georgetown Immigration Law Journal 7 (1993): 649.

17 United Nations, 1951 Convention Relating to the Status of Refugees, Article 1A.

18 Leon Uris, Exodus: A Novel of Israel (London: William Kimber, 1959).

19 The Pale of Settlement was an area in the western Russian Empire in which Jews were granted the right to live. Beyond its borders Jews had very limited rights to reside anywhere else within the empire. The pale was by far the largest Jewish ghetto in Europe from the late eighteenth until the early twentieth century.

20 Uris, Exodus, 229.

21 Ibid., 231.

22 Ibid., 295.

23 Malkki, "Refugees and Exile."

24 Uris, Exodus, 26.

25 Ibid.

26 Ibid., 39.

27 Ibid., 341.

28 Ibid., 30.

29 Ibid., 47. Even today self-organization and political resistance within refugee camps troubles the legal-bureaucratic administration of UNHCR and other agencies that prefer to operate on the basis of the inmates as grateful and passive recipients of aid. See, for example, Guglielmo Verdirame, The UN and Human Rights: Who Guards the Guardians? (Cambridge: Cambridge University Press, 2011), 286; Michel Agier, Managing the Undesirables: Refugee Camps and Humanitarian Government (Cambridge: Polity, 2011), 41.

30 Uris, Exodus, 599.

31 Ibid., 262.

32 Ibid., 546-7.

33 Ibid., 40.

34 Ibid., 235.

35 Ibid., 586.

36 Ibid., 587.

37 Ibid., 605-6.

38 Ibid., 585 .

39 Jeremy Salt, "Fact and Fiction in the Middle Eastern Novels of Leon Uris," Journal of Palestinian Studies 14 (1985): 54-63.

40 Salman Rushdie, Shame (London: Picador, 1984).

41 Ibid., 63-4. 
42 Giorgio Agamben, Homo Sacer: Sovereign Power and Bare Life (Stanford: Stanford University Press, 1998), originally published in Italian as Homo Sacer: Il potere sovrano e la nuda vita (Turin: Einaudi, 1995).

43 Rushdie, Shame, 145.

44 Ibid., 66-7.

45 Ibid., 82.

46 Ibid., 85-7.

47 Malkki, "Refugees and Exile," 518.

48 Rushdie, Shame, 267.

49 Benjamin Zephaniah, Refugee Boy (London: Bloomsbury, 2001).

50 British Prime Minister Neville Chamberlain notoriously used this phrase in 1938 to justify his government's washing its hands of any responsibility for protecting Czechoslovakia from the Nazi takeover.

51 Zephaniah, Refugee, 83, 143.

52 Ibid., 150.

53 Ibid., 230.

54 Ibid., 236.

55 Peter Hallward, "Badiou's Politics: Equality and Justice," Culture Machine 4 (2002), http://www.culturemachine. net/index.php/cm/article/viewarticle/271/256.

56 Zephaniah, Refugee, 189-9o.

57 Ibid., 123.

58 Said, World, 21.

59 Salman Rushdie, "Imaginary Homelands," in Imaginary Homelands: Essays and Criticism, 1981-1991, 9-21 (London: Penguin, 1992).

60 Zephaniah, Refugee, 238.

61 Ibid., 239-40.
62 Ibid., 253.

63 Ibid., 259.

64 Ibid., 260.65 Georg Lukács, The Theory of the Novel: A Historico-Philosophical Essay on the Forms of Great Epic Literature (Cambridge: MIT Press, 1971), 80; Dolin, Critical Introduction, 41.

66 Lukács, Theory, 78.

67 Salman Rushdie, The Satanic Verses (London: Viking, 1989).

68 Hannah Arendt, "We Refugees," in Altogether Elsewhere: Writers on Exile, ed. Marc Robinson, 110-19 (Boston: Faber \& Faber, 1994).

69 Georg Lukács, Realism in Our Time: Literature and the Class Struggle (New York: Harper \& Row, 1971), 23.

70 Edward Said, "Reflections on Exile," in Reflections on Exile, and Other Literary and Cultural Essays (London: Granta, 2001), 144.

71 Malkki, "Refugees and Exile," 513.

72 Kieran Dolin, A Critical Introduction to Law and Literature (Cambridge: Cambridge University Press, 2007), 41.

73 Jacques Rancière, Disagreement: Politics and Philosophy (Minneapolis: University of Minnesota Press, 1999); Alain Badiou, Ethics: An Essay on the Understanding of Evil (London: Verso, 2001).

74 Evgeny Pashukanis, General Theory of Law and Marxism (London: Pluto, 1989), 115.

75 Nevzat Soguk, "Poetics of a World of Migrancy: Migratory Horizons, Passages, and Encounters of Alterity," Global Society 14 (2007): 431, quoting Karl Marx.

76 Patricia Tuitt, False Images: Law's Construction of the Refugee (London: Pluto, 1996). 